\title{
Hitler's Munich: The Origin of the NSDAP
}

\author{
Cinzia Leone \\ Department of Political Science, University of Genova, Italy
}

Copyright $(2017$ by authors, all rights reserved. Authors agree that this article remains permanently open access under the terms of the Creative Commons Attribution License 4.0 International License

\begin{abstract}
Adolf Hitler decided to move to Munich in 1913 and he remained there for more than three decades. Although he transferred to Berlin during his time in government, Hitler always maintained a headquarters in Munich, and he never ceased to regard it with great nostalgia. The future Fuhrer quickly fell in love with the Bavarian capital and made Munich the center of his operations, and the cultural capital of the new Reich. He developed a profound love for the place which harbored him and which stayed with him from the dawn of his career. In this essay, I ask the following questions: what role did Munich play in the development of the National Socialist movement? And if he had not lived in Munich would Hitler have developed into the figure he became? In an attempt to answer these questions I start by describing Munich during Hitler's time, to its antisemitism and the birth of National Socialist party and the centrality of Hitler, and offer a short historical discussion of its position within Germany. Man can surely find some parallelisms with the current situation of our Europe in this essay, where we see nowadays even stronger extremist movements.
\end{abstract}

Keywords German History, Adolf Hitler, NSDAP, Munich, Antisemitism

\section{Introduction}

The future head of the Nazi Party in Germany and architect of the Second World War, Adolf Hitler decided to move to Munich in 1913 and he remained there for more than three decades. Although he transferred to Berlin during his time in government, Hitler always maintained a headquarters in Munich, and he never ceased to regard it with great nostalgia.

The future Führer quickly fell in love with the Bavarian capital and made Munich the center of his operations, and the cultural capital of the new Reich. He developed a profound love for the place which harbored him and which stayed with him from the dawn of his career.

In this essay, I ask the following questions: what role did Munich play in the development of the National Socialist movement? And if he had not lived in Munich would Hitler have developed into the figure he became?

In an attempt to answer these questions I start by describing Munich during Hitler's time, to and to its antisemitism and the birth of National Socialist party and the centrality of Hitler, and offer a short historical discussion of its position within Germany.

Man can surely find some parallelisms with the current situation of our Europe in this essay, where we see nowadays even stronger extremist movements.

\section{Munich in the Nineteenth and the Early Twentieth Centuries}

Munich was a city in ferment at the turn of the twentieth century. The political transformations the city experienced had significant implications and these came entirely from social changes.

Munich's metamorphosis into a large modern city was not an easy process. Unlike other large German cities, it failed in its attempt to become an industrial center. Even though it was lagging behind economically, the population rose steeply towards the end of the nineteenth century - from 34,000 official residents in 1800 to 596,000 in 1910 [1]. At the turn of the century, almost half of Munich's inhabitants were not natives. Many were immigrants, from the east and from other parts of Germany. Problems arose as a result of this population growth. There was a lack of housing, jobs and essential services (such as water), and a rise in prices.

The importance of the aristocracy began to noticeably diminish, in direct proportion to the rise of new groups of professionals who combined Bildung und Besitz [2]. The traditional class structure in Munich society was threatened by significant social mobility, which intensified whenever there were large migration flows.

These social changes inevitably had political consequences. Throughout the nineteenth century, the economic and academic elite had played a dominant role in the field of politics. The right to vote was limited, and overwhelmingly favored the aristocracy, enabling it to maintain its power. But then, at a certain point, things began to change. 
Although very active culturally, and fairly developed as far as international tourism was concerned, Munich was not a cosmopolitan city like Paris or Vienna. It vigorously maintained its Bavarian character and its strong sense of belonging to the region of which it was the capital. The 1871 reunification with the Reich represented a break with the past and a moment of crisis for the city. Yet Munich also experienced a new deepening and reinforcement of its identity, just in open contrast with the dominant Kulturkampf, the cultural struggle registered in the period between the German north and the catholic south of the country. As a reaction to the political changes to Germany's state and society, in Munich this desire expressed itself in the birth of diverse political movements and parties in a relatively short period of time.

Thus, in 1868, the Patriotenpartei was established in Munich by militant Catholics. The party represented a reaction against both liberal ideology and the attempt at forced Prussianization. The following year, at the election of the Bavarian Landtag (the parliament), this party of patriots achieved a majority. The new party was by no means open or modern. On the contrary, it radically evoked national values, in a way that was ultra-nationalistic, racist and antisemitic.

The Social Democratic Party was founded in Munich in the same period. In 1896 the recently-founded party immediately obtained 14 percent of the city council seats, thanks to its reformist and pragmatic character. Thenceforth it established itself as a popular political movement.

Bavaria, a traditionalist land, deeply attached to age-old values, needed a change. It needed something powerful - a party, either social-democratic or patriotic in character, which could defend its identity, and maintain a distance both from liberalism, which threatened tradition, and from unpopular Prussia.

Many dangers threatened to undermine the strength of Bavarian traditions: not only progress, industrialization, and liberalism, but also unemployment, social corruption, the waves of new migrants, the Kulturkampf, and the rivalry with Berlin. As has often happened in history, the Jews were seen as a threat; many people in Munich believed they constituted the greatest danger to society. Different parties and cultural associations began to spread antisemitism vigorously, identifying the Jewish enemy as the source of many social ills. The growth in the Jewish population in the city, though limited in extent, was accompanied by an increase in hatred towards them.

While Munich had the largest Jewish community in the south of Germany, this community was not as extensive as those in cities such as Vienna, Prague or Berlin. The Jews arrived from Galicia, Poland and Russia, as well as from other parts of Germany, along with many other immigrants from those regions. Despite this, the University of Munich was referred to by the right movements as a "secularized Talmudic high school". Antisemitism was also evident in magazines and it could be heard in popular songs. Biological determinism was spreading among the people.
It was in this particular place and context that another party was founded in 1891 - the Deutsch-Sozialer Verein (DSV). The DSV was a profoundly antisemitic party, which supported the expulsion of all Jews from government positions, a decrease in the percentage of Jews in the professions, and restrictions on immigration to Munich.

The propaganda center of the Alldeutschen Verband was also in Munich. This nationwide movement espoused an extreme nationalism, and a strong aversion to anything that was not German - foreigners and Jews included. It expressed the "hope that Germany would produce a new Luther, a man who could carry forward and lead a struggle" [3] - a common phrase of the period with antisemitic undertones of a Christian cast. They were waiting for a messiah, someone who would turn back the tide of German misfortune, someone who would revive the great militaristic Germanic dream that had never died.

The conviction that a new leader (a Fuhrer) would arise, to fulfill the expectations of a people who would be his followers, was widespread in Germany (and Munich was the epicenter), and not only among right-wing groups. The leader was conceived not as someone who would control others by virtue of his political position and power. Rather, the person who possessed the gift, the instinct, the quality of leadership that was innate, natural, recognizable from the outside, and identified as such by those around him, could and would become the leader. Thus was expressed the Weberian[4] idea of the leader, the Weberian idea of the practice of leadership, and of the assertion of power, even in the face of opposition, which was legitimized by charisma. This legitimacy rested on the firm foundations of the leader's sacred and ritualistic personality, and on his heroic strength and charisma. This represented the Führerprinzip, which found embodiment in the figure of Hitler and which he himself exploited when he wanted to overcome every formal constraint, and free himself from all the restrictions of the state apparatus, to unite all power in his own hands.

These principles were ever present in German thinking and were hence the expression of a profound need of the German soul. There is no community without a strong leader, no nation without a Fuhrer, but only perdition and vain hope.

This yearning was expressed by the famous legal expert Carl Schmitt, who defined socio-political "normality" as a state in which there is a leader and a nation of followers: «It is necessary to create normality; the sovereign is he who decides definitively if this state of normality prevails.» [5]

Schmitt habitually and vehemently criticized the work of the democratic constitution. His thinking became a powerful leitmotif during the fragile Weimar Republic, where the need for clear leadership became increasingly obvious, with a weak political class, lacking strong personalities, and in an uncertain historical context, and at a time of abject German humiliation following defeat in the First World War.

Hitler offered the perfect response to this demand for a leader, and his organization was founded as an essentially grassroots movement. From the very beginning it distanced 
itself from the highly unpopular conventional political parties, and remained outside the framework of the traditional party system. That was precisely the reason he won approval and support, where a Fuhrer was regarded as the solution to the crisis: over the weak lifespan of the Republic (1918-1933) there were no less than twenty governments and twelve heads of government. Hitler was the thirteenth. Many believed he would last no longer than his predecessors, but their predictions turned out to be completely wrong, as stated by following affirmation: «I would have made fun of anyone who had prophesied that this represented the beginning of a new era of world history.» [6]

\section{Weimar: A Weak Democracy}

In January 1919[7] the Republic emerged out of the ashes of the lost war, and was weakened by the Treaty of Versailles[8]. It had lost territory to the east, west and north, and all of its colonies. It was now forced to disarm, more or less completely, and to pay high reparations: the Versailles Treaty did not treat Germany as a defeated state that was still part of the international community, but as a convict and an exile. This is how the German people felt, and they were right to feel this way since that was exactly how they were treated. Many Germans did not even want the country's leaders to sign the treaty; despite their clamorous defeat in the war few could accept such humiliation. However it would have been impossible for them to have endured the consequences of not signing, such as the threatened occupation of Germany by the Allies, and the division of the German state. Germany, which even before the beginning of the war had felt surrounded, now found itself squashed between the victorious allied powers. Meanwhile its ally to the south (the Austro-Hungarian Empire) was disintegrating, and being replaced by weaker political entities which would sooner or later fall under German influence. As a result, and despite what the most part of population thought, after the war the position of Germany was strengthened from both a geographical and a strategic point of view. Moreover a great empire (The Soviet Union) had recently emerged in the east, which was regarded by the western powers as a much bigger threat than Germany. To the south the bastion of conservatism and order that was the Habsburg Monarchy had disappeared. Germany represented the last step before the unknown.

After Versailles, the Soviet Union ceased to be interested in the West, leaving field open to the other two great powers, France and England. The pair, united only in their aversion towards Germany, were sufficiently satisfied by the peace treaty. Although the danger posed by Germany had diminished, expansionist aims in Europe were not appeased.

In this historical and geopolitical context, the arrival of democracy in Germany did not constitute a new beginning. It was clear from the outset that the newly-born Republic was the source of problems that would lead Germany to the
Hitlerian disaster. For many people during the Weimar period the word "democracy" represented weakness and betrayal rather than strength and hope. The sense of fear that was present in the German society was heightened by the political situation. Indeed the new democratic state did not establish any durable authority. It did not appear to be active, engaged or able to live up to expectations; no one believed it would last. In German history and tradition the state had always been powerful and fundamentally important; German society was indeed founded on the idea of the state. Unlike in other European states, the idea of the state was part of the mental landscape of ordinary citizens from birth. The lack of a clear and lasting guide or reference point, and the impossibility of identifying oneself with such a weak state, weighed extremely heavily on the psyche of the German people. This was compounded by the recent military defeat, which had broken and humiliated them.

From its very inception the Weimar Republic had to face not only political disillusionment, but also an economic crisis. In his discussion of the Weimar period, the Austro-Hungarian and smart observer Stefan Zweig wrote in different essays that nothing pushed the German people towards the arms of Hitler more than the inflation of 1919-23, which left an indelible mark on German society. Moreover, among the others, also the essay of Joachim Fest about Adolf Hitler admirably explains the process by which the German people were prompted to adhere to, and identify with, National Socialist ideals. The antidemocratic Führerprinzip theorists could not find the leader they yearned for in the real world. As a result, they indulged in more abstract and elevated meditations, formulating a divine mission for a future national leader endowed with quasi-supernatural gifts, which were summed up in the German expression Führerbegabtheit. This referred to someone with, to use a phrase of the period, the "divine spark in his heart", who did not operate according to conventional rules, who derived power and strength from his own soul.

The nation, for its part, should prepare for the advent of the Fuhrer. As one Volk (people), and as one Germany, it should pave the way for the country's renewal, for its coming greatness, which would be rediscovered by the new leader, as Ernst Jünger commented in 1920: «In our misery we long for a leader» [9]. Along the same lines, a few years later, the philosopher of law Julius Binder declared: «The Fuhrer cannot be fabricated ... he is self-created... He is the soul of the nation... In the momentum of history... we recognize the soul that governs the world.»

The advent of the Fuhrer thus became a metaphysical concern, rather than a political reality. Over time, his characteristics and virtues became more clearly defined and elaborated. It was said, for example, that the Fuhrer could in no sense be a liberal because liberals were too open to negotiation and compromise - attitudes and approaches that had led Germany to agree to pay high war reparations, and which had destroyed its pride and crippled its economy. Germany's required leader would have to embody the 
principle of autocratic decision making; he would be inspired by German blood and history, rather than political calculation. To quote a phrase then current in ultra-antidemocratic circles: «The true statesman is history itself» $\rangle[10]$. This idea represents the consummation of the romantic myth associated with Herder, in which the nation is conceived as an organic entity that comes before the state, and is linked to blood, language, race and ethnicity. In other words, the nation is embedded in the soul and cannot be imposed or fabricated because it is not artificial. The period, the historical moment, necessitated this attitude to nationhood.

One of the failings of the Weimar Republic was that it underestimated the extent of the people's desire for a leader; it took for granted that this desire would readily translate into identification with democracy. Hans Kelsen[11] identified the absence of a leader as one of the positive traits of democracy; perhaps the Germans would have agreed with him had the Weimar Republic been a solid and successful democracy. But it was not. The official state did not fulfill expectations, and it indeed became fashionable to hate the Weimar Republic. Democracy was regarded as too weak.

The power of the attraction exercised by National Socialism - above all at the beginning - was of a spiritual kind. It offered man the possibility of overcoming the isolated individualism to which he had been condemned by diverse forces; it aimed to create a socialist and nationalist (or rather a National Socialist) being, to take refuge in lost values. These values offered the possibility of safety and security. In this way capitalism and industrialization, and all the ills they brought with them, were not completely rejected. A way out was found firstly in the sphere of the spirit and secondly in that of politics, which would come to represent the external projection of the inner man: «Germany? ... no-one knows where it begins or where it ends. It has no borders, Sir, in this world ... it exists in our heart ... or it will never be found anywhere.»[12]

The failure of middle-class forms of life wrecked the foundations of society. This created a feeling of uncertainty which united with those already extant feelings of insecurity and fear that had been produced by other factors. These feelings formed the basis of National Socialism's success.

Hitler, for his part, exploited to the utmost his rhetorical skills. With these skills he "tamed" the masses, and molded them so they would agree with him and identify completely with their leader, by using powerful words and images. He incited them to hatred and revolt. One of the phrases Hitler most liked to repeat was: «All that is left to us is disgust and hatred, hatred and yet more hatred!»[13]. Hitler's speech was direct and uncompromising, awoking the antidemocratic instinct of the people. Without the conditions summarized above it would have been in no way possible for the NSDAP to have become so successful in such a short space of time, hailing as it did from a traditionalist and conservative region like Bavaria, in a time when a kind of millennial spirit pervaded the people: «Our Fuhrer will restore honor to the people! ... We will not endure any longer the shame of this republic... Germany has lost its honor and only the Fuhrer, only the Fuhrer, can restore it!» [14]

Many historians have seen the revival of this grand-national and nationalistic idea within the context of the political dysplasia of the First World War. However, it could not have come from nowhere. These phantasmagoric ideas concerning a great German Reich that could become the strongest European power, along with the ideology of a Germania triumphans and of German supremacy within Europe, evidence continuity with the German past. Racial purity and the destiny of the German people were hymned by many poets. They were also the refrain of many well-known popular songs and countless writings that nurtured the myth of the power of the pure and superior nation. Just for example, Jörg Lanz wrote in 1908: «This race of noble blood, if it remains pure, will not succumb. The day will come when these men will be sought after and rewarded». [15]

In such writings racial cleansing through euthanasia and the 'final solution' were put forward as the means of achieving the longed for purity and elevation of the worthy Aryan population. Poets' verses provided the accompaniment to the wishes and desires of the German people, and they sang about the people's future.

This was the period Germany was living through at the turn of the century: that of a dream that had by that time taken root in the consciousness of many, a dream that Hitler himself became aware of by reading these texts and by living in Munich.

From the above and also from other ideas (which for reasons of brevity I have not been able to analyze here) Germans easily arrived at the idea of the Reich, which became established with the coming of Hitler: «The decisive significance of the idea of the Reich lies in the fact that it gave a positive value to the German present. ... Through faith in the Reich, memories of the past and unresolved problems are not reawakened ... hopes for the future are also strengthened.»[16]

All of this was accompanied by new ideas concerning the people, nation, society and liberty. This was supposed to work (also from an ideological point of view) for the new foundation of the state with a secure leader. In that state people would be subjugated. The concepts of the people and the nation would form a unicum that would facilitate the state's success: «The nationalization of the masses cannot be achieved through half-measures or by emphasizing so-called objectivity or impartiality, but only with fanatic, unilateral and resolute planning, directed towards the achievement of the objective.»[17]

Over the years Hitler developed an awareness deriving from the revolutionary idea that the masses could play an active role. In the German tradition of the nineteenth century, man could become a protagonist of history and politics, rather than their tool, by participating in mass movements. This is evidenced by the widespread participation of enormous crowds in Nazi assemblies even before their rise to 
power. These crowds participated spontaneously, moved by the great importance that was attributed to these events. Historically speaking, the Germans had, more than any other people, a sizable number of associations which coordinated, by means of order and discipline, the cult of the nation and fatherland, and which exalted it though theatrical displays of every kind. Thus Hitler found the way prepared for his ascent to power. When he wanted the masses to follow him they were ready to do so. It is precisely in these movements that perhaps the origin of the National Socialism is to be foundit was their historical and significant presence in German society that laid the foundations of National Socialism's ascent. This bears out something Friedrich Nietzsche wrote: «Fanaticism is the only form of "will power" in which the weak and insecure can participate.»[18]

The German spirit lived and manifested itself in every single individual, though no longer, and not yet, in a party. Each person was thus part of an organic complex that passed through the identification of the individual to the mass, bypassing the failed system of parties which, up until then, had represented the only way an individual could express him or herself.

In that time, and also before the Hitlerian period, the idea of liberty was also revived, alongside the idea of equality. From the French Revolution onwards these concepts and values acquired great significance everywhere, but not in the German territories. In fact, the ideals of the Prussian Reich were those of power, order and discipline. Its values were obedience, war, industrial power, administrative power, and submission. According to many observers, there was, historically, a certain resistance in Germany to the potential development of middle-class ideals.

In contrast to France and England, the Enlightenment and political humanism were completely blocked in Germany because of the indifference of Lutheranism to them and because of the country's territorial division. Because of its political and religious history, the German Reich did not have any link with a century that was decisive for the culture and formation of the modern world.

As a result of the typical and unavoidable German characteristics of obedience to orders, submissiveness, and affinity with authority, the identification of the people with prenationalistic, German national, and kaiserlich-predemocratic interpretations of the phases of the Prussian Reich, as well as the most important antidemocratic currents during the Weimar Republic, naturally had a powerful effect. Political humanism was completely alien to Prussia. The ambition of Prussia was more inclined towards the revival of the universal medieval state.

\section{$[\ldots]$}

While the French Revolution had raised the question of a new ethics, the ethics of man, and of the rights of people for the common good, in Germany there was a military regime led by people with prophetic pretensions.[19]

The cultural formation, as well the social stratification of nineteenth-century Germany, reflected the total absence of any influence from the French Revolution. That said, there were nevertheless German thinkers and philosophers who yearned for fraternity, liberty and equality. The anti-liberal attitude of the state led to the replacement of the democratic principle of equality with that of hierarchy. The idea of the self-determination of populations was taken up again in response to people's desire for emancipation from the chains of Versailles. Liberty came to mean the freedom of belonging politically to a state dominated by a leader and no longer related to personal freedom and self-determination.

\section{Munich: Crossroads of the Discontented of Weimar and the Cradle of the NSDAP}

The Munich in which Hitler lived became, after a few year years, a place where the unhappy and dissatisfied congregated. One of these movements was the party that would make history thanks to one of its members, Adolf Hitler. The Deutsche Arbeiter Partei (DAP, German Workers Party) was formed in January 1919, in the shops of the Munich railway, by the toolmaker, Anton Drexler, along with Karl Harrer, Gottfried Feder and Dietrich Eckart. In that year there were about fifty political groups in Munich, whose names echoed their intent: Neues Vaterland, Ostara-Bund, Bund sozialer Frauen, Siegfriedring, Freie Vereinigungsozialer Schüler and others. The DAP also belonged to the ranks of these associations, which proliferated in a period of social uncertainty and new political awareness.

In September 1919 Hitler went to a political meeting: he did not wait long before making his own contribution, astounding listeners who immediately recognized his rhetorical skills. Within six months Hitler succeeded in consolidating his position as the leader of the party and he was thus able to take decisions that would be key for both himself and for the development of the party. The faithful Hermann Esser became chief of the propaganda and editor of the Völkische Beobachter, a Munich newspaper which became the official organ of the movement and the center of National Socialist propaganda. Among the first adherents there were other characters, who left a mark on German history. Rudolf Hess e Hans Frank, for example, came from radical right-wing groups. There was also Heinrich Himmler, at this time a student in technical school, whose father was a practicing Lutheran and a teacher in a famous Gymnasium in Munich. He later became one of the most important protagonists of the Third Reich, performing a number of roles. The Bavarian He $\beta$ wasn't a very good student, but 
from the very beginning he fought at Hitler's side; he also designed Hitler's advertising posters. During his stay in Bavarian prisons after the putsch of 1923 he helped Hitler write Mein Kampf. Hess would become number three in the NSDAP command, after Hitler and Goring. Frank was a law student and a member of the Thule and the Freikorps "Epp". Among many others things, he founded the first National Socialist student group and became the lawyer of the NSDAP. After the conquest of Poland, Frank was nominated "General Governor of the Occupied Territories", and he would be responsible for the murder of hundreds of thousands of people.

Alfred Rosenberg also joined the group from the beginning. A German from the Baltic region, Rosenberg was born in Estonia. In Munich, from 1918 onwards, he formulated the ideology of National Socialism, becoming the personal adviser of Hitler, and the chief editor of Völkische Beobachter. His ideology can be summed up with the following phrase, which was written by Rosenberg himself during the Nuremberg trials: «National Socialism is the most noble idea to which a German could dedicate all of the strength given to him (or her).»[20]

Rosenberg confirmed the antisemitic creed of the National Socialist party. He was responsible for importing to Europe the famous Protocols of the Elders of Zion from Russia and the principal exponent of Lebensraum, of paganism and of the theory of racial superiority. He despised Jews, Slavs, Latins, Africans, leaving only Aryans as the chosen people.

The fact that Rosenberg went straight to Munich, on abandoning lands that had fallen into Bolshevik hands, rather than to another German or European city, appears significant and paradigmatic: «Several people within the group of men close to Hitler came from abroad. Like Hitler himself, they were from the fringes of the German territories and did not have German citizenship.»[21] Like Hitler, Rosenberg succeeded in obtaining German citizenship in Munich - in February 1923, only five years after his arrival from Russia.

Having entered the DAP as member number 555[22], Hitler immediately embarked on political and organizational activities. Prompted by his suggestion, in February 1920, the DAP transformed itself into the NSDAP, absorbing into its name the Nationalist and Socialist program. The party became very popular throughout Munich: in 1921 it already had 2,500 members and 45,000 supporters. It achieved great success in the elections of February, when it invested heavily in meetings and in direct contact with the people. In fact in Munich alone there were at least forty NSDAP rallies during the campaign - an unrivaled total for any party in any German city.

Adapting various propaganda techniques from other parties (and even from his adversaries), Hitler expended all of his strength disseminating the new creed in Munich. This was an intense and frenetic period of activity for Hitler: he would race from one side of city to the other and address six rallies on a single day.

From the very beginning Hitler demonstrated his political gifts. His instinct and skills were undoubtedly key elements in the success of the movement. Indeed, not for nothing was he called the "Don Quixote of Munich" by one of his first biographers in 1935. Endowed with cold blood and excellent political instincts, he had the ability of taking hasty decisions that turned out to be successful. This skill, along with his effective use of the media, established Hitler, over time, as the only possible alternative, and as the only man capable of leading the NSDAP.

Meanwhile, the members of the Hitlerian party recruited, in a frenzy of activity, new affiliates from the lower ranks of the local population. Many of those who joined the new movement were ex-soldiers deeply disappointed by defeat in the war, and by the politics of Weimar, and by their inability to resettle and find work in a new society without soldiers. In the character and ethos of the new party they found elements that corresponded with their own backgrounds: a strong emphasis on discipline and order; a clear, predefined hierarchy; and the use of violence as a means of fighting in the sphere of politics. The military stamp acquired by the (NS) DAP right from the beginning offered Hitler the opportunity to develop a strong, closed and hierarchical internal party structure, and to ensure that everything concerning the party revolved around him. Thus Hitler was always surrounded by a troop of soldiers who obeyed him, protected him, and gave him security and success. The structure of the party did not modify over time.

In its early years, the number of NSDAP members doubled when Julius Streicher joined in Nuremberg. Born in Upper Bavaria, this prominent elementary school teacher loved to style himself "antisemitism's world fighter number one"[23]. He founded a weekly magazine, Der Stürmer, through which he disseminated his sick and hateful propaganda against the Jews (whom he disdainfully referred to as "alljuda"), without ever experiencing the slightest censorship from the authorities. From 1923 onwards the periodical - which was loved by Hitler - printed antisemitic tirades, with phrases such as "there can be no redemption for mankind without the solution of the Jewish problem" and "the Jews are our misfortune". This latter phrase was printed everywhere by National Socialists some years later and, sadly, became famous.

Heinrich Müller, a native of Munich, was one of the few "privileged" participants of the Wannsee Conference organizing the final solution. Müller came from a lower middle-class, ultra-Catholic Munich family, employed in the Munich police department and in 1929 he became the secretary of the city's political police, which fought against Communist organizations. Later on he joined the SS and embarked on a career that took him away from Munich, focusing on the "Jewish Question".

Adolf Wagner, who hailed from Munich, was Hitler's ever faithful brotherly companion. An alcoholic, an art lover, and a vehement anti-Catholic, he was the true "voice of the Fuhrer". He delivered public speeches on behalf of Hitler, 
when the Fuhrer was unable, imitating him perfectly. Wagner was one of a handful of Hitler's intimates and he would remain close to the Fuhrer until the end. Whenever Hitler returned to Munich, during his years of government, he always found his faithful friend waiting for him.

Thus the National Socialist elite came, in a large part, from Bavaria, and did not change from the early years of struggle to the later years of government. In its lower ranks, however, the turnover of personnel was high, at least until 1928, when the party organization changed. At that time the party was not a cohesive body, especially at a local level; its functionaries and participants worked together in an entirely uncoordinated and improvised way. There was no systematic organization or clear distinctions of responsibilities within the party. The management had no training in politics - they did not come from political schools and no one had taught them how to perform their new roles. Typically belonging to the lower middle class, their work for the party bore the stamp of their background and education.

Traditionally civil servants were under the control of the government; they were faithful, in political terms, to whoever was in power. However, this did not occur automatically under the Weimar Republic. Thus it seemed legitimate to them to support a political movement that was against the status quo. Weimar did not represent the desired continuity with the past. In fact, from 1918 onwards, the fear of confronting the future increased within this group, linked to the precariousness of the situation, following defeat in the war, and to the Communist danger that was menacing life, and undermining further the constitutional order. To them National Socialist slogans alone were enough to constitute a patriotic bulwark. The discontent of public workers was exacerbated by rampant inflation. Economic insecurity added to their disgruntlement and this is why they looked to the new Nazi movement for solutions and consolation. By summoning up and evoking simple, archetypal values, such as nation, country, virtue, and purity, the movement effortlessly appealed too many.

Nazi propaganda tempted the farmers too (even if they often kept their distance from politics) for the same reasons it attracted white-collar workers. Like that group, farmers had a fear of the 'other' that was often related to resentment towards Jews.

Students and youths supported the party fervently and comprised a significant part of it. Until this time young people had, generally speaking, not been greatly politicized, and they had shown little interest in political events. At the end of the First World War many young soldiers found themselves jobless and without any prospects for future. They saw in National Socialism the possibility of succeeding in both the social and personal spheres. Other young people were passing through a moment of intense disillusionment; economic insecurity exacerbated this. The National Socialist party offered everyone the chance to play sport, and to join wrestling clubs, along with a powerful ideology, which they could identify with and in which they could believe. Some organizations were not only politicized but also armed. These groups gave a sense of security to large groups of young people who rushed to join the SA or the SS (these two groups of militarized extremists were founded in Munich long before Hitler's rise to power in 1933). Inside both these organizations military battalions were formed specifically for students. The first military formation of the SA comprised exclusively of students was created in November 1922 when the Völkische Beobachter called together a group of radical students for a meeting in a Munich pub.

Blue-collar workers and members of the elite dominated many political parties during this period. However, contrary to what many people think (such as Lypset[24]) these social groups did not dominate the National Socialist party. The National Socialist movement did not leave historians and scholars much clear and objective evidence and this makes it difficult to draw a coherent portrait of its members and their sense of social belonging.

While the lower middle class always dominated the party's membership, the number and importance of members from the social elite was nevertheless significant. Even though we only have a few statistics at our disposal, it is clear that academics and university students (a sub-group of the social elite) were always well represented within the party. Until 1930 the social elite comprised between 6.3 and 8.8 percent of the party's membership, maintaining a significant if not a dominant presence within the NSDAP.[25] An internal directive dated 1922 provides clear information concerning rules related to the party's social composition: every local group of the party had to accurately reflect the composition of the society surrounding it, and, under no circumstances, were academics to comprise over a third of a local party's management.

Another element that attracted many people to the party, distinct from the activism and militarism which appealed to youth, was the anti-liberal tendency in its opposition to the new republic, which it regarded as too democratic to be strong. Various clubs of businessmen and directors in Munich supported the National Socialist party discretely through constant subsidies, without making public declarations of approval. Nationalism represented for many intellectuals an aesthetic spiritual quintessence in which they could invest complete confidence. From the very beginning large numbers of academics supported the Hitlerian movement. One outstanding example was the Nobel-prize -winning scientist Johannes Stark, who joined the party in Munich[26]. One might add, moreover, the generally atavistic aversion of the most part of the social elite towards Liberalism, which they regarded as degenerate - and in this they prefigured the attitude of National Socialism.

As confirmed even by Joachim Fest[27] it was an entire society, made up of diverse elements that willingly chose to follow the National Socialist ideal; there was no dominance of one social group over another. The Hitlerian ideal was for 
everyone, and everyone was united.

\section{The Reason for the Nazi Success}

The ideal was a concrete proposal for a world full of disorientated people who collectively were experiencing, from both a personal and a social point of view, a pathological discontent without parallel in any other European society at this time. Hitler wanted to mobilize the German society in a movement of resistance to the disorder of the Weimar period. In this he imitated some of the illustrious precursors from whom he took inspiration, such as Karl Lueger[28]. Hitler himself repeatedly said there was no place in the NSDAP for those who wanted to bring their backgrounds with them - their sense of kinship with a class or social stratum: in fact, the NSDAP demanded a loyalty and support that was not founded on class but on a particular mentality, a way of thinking about the world and about oneself - the mentality of someone who was entirely and wholeheartedly National Socialist, identified with the party not so much as a political idea but because he felt at home there.

Thus, the NSDAP became shortly the focal point and consolidator of the German nationalism, which was spreading and intensifying both inside and outside of Bavaria. In Bavaria the memory of the Communist coup[29] failed in 1919 was still very much alive. That is why government officials and the police regarded Hitler sympathetically, even when they were not members of party. These were the people who protected Hitler and who neglected their duty by failing to prevent many of his actions.

Unlike other successful political parties of the period, the Nazis never focused their attention and activities on economic inequality and disparity between the various social classes. Rather, they directed their efforts towards fostering a sense of identification based on biological criteria and on the idea of a shared destiny, where the pure Aryan blood could eventually affirm, after the suffered long abuse by side of the non-pure, the Jews, in particular by side of the Jewish bank owners. There is evidence of this attitude from the beginning of the DAP movement: in the program of Feder, emitted on 24 February 1920, there were clear references to race and to antisemitism[30]. This was a union in a negative sense of the word, a union which aimed to preserve something threatened by the surrounding world. It was a coalition established to defend a citadel under siege, and a people whose pure blood was being undermined by the enemies of the race and by the Jews. Over time this element became predominant. In this way, the Nazis did not make references to the workers or to the farmers for class reasons, nor was their focus on capitalist exploitation. The Jewish banker and the Jewish merchant were the enemies against which one had to fight - the enemies one entered the field of politics (as well as the streets) in order to confront. They were accused of speculating and exploiting the pure-blooded and long suffering German people by making unjustifiable profit out of their savings (which Germans had made great sacrifices in order to accumulate). According to the Nazis, the presence of the Jews in German society also threatened to contaminate the German race. By reformulating its slogans and by fine tuning its message the NSDAP was able to become more powerful, first in Munich, then in Bavaria, and then throughout the rest of Germany. It was reinforced further by the racial and racist element, which created a bond that might have appeared unstable and superficial but which, in the long run, turned out to be deep and durable.

Thanks to all these events the party went from having 55 members in 1919 to 55,287 in 1923.

Over time the NSDAP became increasingly organized with its Sturmtruppen Abteilung (SA) and the Stoßtrupp Hitler (Shook-Troop Hitler) - the prototype of the SS.

Many people who joined the party felt a profound and Darwinian admiration towards Hitler; they greatly desired to copy him, and were willing to follow him anywhere.

Among the NSDAP membership there were many who had developed psychological problems of adaptation to the new society in which they found themselves. By joining the party these people had found, to some extent at least, the solution to their problems. Histories of the Third Reich are full of descriptions of slightly strange, psychopathic, or 'borderline' characters who flooded the ranks of the party and the same Hitler represents an eloquent example of that. The NSDAP offered various social groups easy answers to their questions. As a result, in the election of September 1930 the NSDAP unexpectedly became the second largest party in the Reichstag, slightly increasing its number of seats, which were 12 in 1928 and increased to 107 in 1930 (out of 577)[31]. The Nazis successfully used Munich as a springboard. The city allowed the party to evolve from a tiny, and far from cohesive political movement, without a clear program, into a big national party with a large representation in the Reichstag. In 1932 it achieved even greater success. Support for the party quickly spread on a national level, even reaching as far as the north of the country.

While many people in rural areas of Bavaria did not become party members, even due to Catholic opposition, they had no difficulty or compunction about voting for the NSDAP, which successfully channeled their feelings of discontent about the rural depression. In Bavarian regions such as Franconia the success of the party was greater. Those who joined the party always did so of their own free-will and the membership never exceeded 10 percent of the population. However, things changed in the years following 1933 as many joined the party for opportunistic reasons: «Men joined the party for work-related reasons - to get or maintain a job, or to get a better job or to avoid having to get a worse one; and in order to get or keep a contract, a supplier, a client or a patient.»[32]

Many have noted that the management of the NSDAP did not correspond in any way to the standard management of traditional parties. The NSDAP did not have great 
experience either as a party or as a government and it did not even have its own school of politics. When the NSDAP went from being a movement to a system, there was a significant physiological turnover of functionaries in its low and medium ranks. In contrast, the leadership remained a strong, stable and close-knit group, which dated back to the early years of movement, to the years of struggle. It had its roots in Munich. In this way, even before it came to power, the party strengthened itself by recruiting skilled organizers from the middle class and from academic circles. These men were distinct from the traditional German political elite. They had fewer social ties, little tolerance towards institutions, and no scruples when it came to reaching a goal. They did not have to answer to anyone regarding their actions apart from Hitler himself and having the same goal was the cast-iron link between the conservative and authoritarian management and the National Socialist leadership: the common aim was the destruction of the Weimar Republic, and by chasing this the NSDAP pursued at the political integration of diverse social interests, using unifying words linked to anticommunism and antisemitism, and to resentment towards the "traitors of Versailles". To the same end they intensified the cult of the Fuhrer who, over time, became ever more omniscient and infallible.

Around 1928, when Gregor Strasser was placed in charge of the organization of the party, Hitler carried out a 'cleansing' of its functionaries. This marked the final confirmation of the dominance of the Munich group, which in turn resulted in the beginning of the cult of Hitler. These were the foundations on which the success of the NSDAP was built: the Munich-style organization and the myth of the Fuhrer (Führerprinzip). Thus it was a negative party which used political and social anger per se, utilizing the "mobilization of discontent", and using slogans that caught the attention of all the social classes, such as "national revival" and "popular uprising"[33]. It was a horizontal organization, with only one summit: Hitler. There was never a formal division of roles and tasks, and this continued during the years in which the Nazis were in government. There wasn't a clear distinction between the party and the state, so much so that it was defined as a "government without administration". The totalitarian affirmation of the Führerprinzip justified the elimination of the democratic principle, along with decision-making assemblies, discussions and elections. In five years (from 1933 to 1938) the party got rid of all the institutions which constituted the civic social fabric in other European countries. Thus was realized the dictatorial alternative to the previous period, seen by many as one of democratic and administrative chaos:

The informal style which began in 1934 corresponded to the command structure that was already present in the NSDAP from 1920. This structure gave Hitler and his small Munich group absolute control over every section and aspect of the party. The Führerprinzip, which Hitler introduced into the party in the early 1920s, and which pervaded its every sector, dominated every form of expression of the party's will [34].

The main innovation of the party was the inauguration of a new political style through which all its members and supporters fully participated in the party during ever vaster popular meetings. These gatherings evidence that new political style which flourished from the wars of national liberation against Napoleon to the political liturgy of the Third Reich.

The aesthetics of politics was the force which welded together myths, symbols and the feelings of the masses. ... The terrible aims for which [the new political style] was ultimately used were concealed from most of the population behind the mask of the attraction exerted by the new politics, and by its effectiveness in seducing the dreams and expectations of the population. An idealized beauty gave substance to the dream world of happiness and order, and enabled men to get in contact with those supposedly unchangeable forces, outside of the sacrifices of everyday life[35].

In this way participants in the new style experienced that dream world of happiness and of Arcadian order which enabled them to live and to see with their own eyes the very myths and symbols that inspired and nurtured that style. The theatrical and scenic politics introduced by Hitler through the use of symbols, torches, parades, and choreographed rallies, turned politics itself into a mere melodramatic production, which was entirely fictional and consisted solely of outward appearance, attracting the interest of the masses who indeed felt they were the focal point and principle actors of Nazi meetings.

The new politics became a new religion, a lay religion that replaced Christianity, which was already being questioned by some before National Socialism's advent, and seriously threatened by the whole movement. Hitler's political style was not, however, merely a tactic to gain power; rather it awakened something that was already inside the people. It was, in other words, a lever with which he lifted a people who would follow him until the very end. Through his utilization of the psychology of the masses Hitler affirmed a new concept of the general will. This new concept was superior to the personal will, bypassing the individual and his or her desires to reach a new national mysticism and an «objectification of the general will that transformed political action into a dramatic spectacle in which the people themselves were the actors.»[36]

Thus the national identity coincided with the general will: the masses were the people, eventually under the right Führer.

\section{Conclusions}

In taking distance from every other movement and party, National Socialism showed itself to be, from the very beginning, not a movement imposed from above but a real 
grassroots movement, which came directly from the mobilization of the masses themselves. And it is precisely because of the identification of the people with the movement, and the fact that it extended to all aspects of individuals' lives, that one can say it was a total movement which wanted to replace not only the existing political system but also history and culture with the new beginning of a new people in a new Reich. After the regime became a dictatorship, and after the mentality of the people had been fully and openly manipulated by propaganda, there was no possibility of the Germans mobilizing political powers against the Nazis. In the eyes of the majority of the German people Hitler's party remained for years the only plausible solution. Because of the propaganda that permeated every aspect of their existence, Germans were not able, or were not allowed, to think of any alternatives.

It is undoubtedly true also that the NSDAP became stronger and more widespread because of ethical indifference and a lack of moral resistance among Germans. In a long period of instability it became very important to look out for one's self interest and attempt to re-establish one's position in every sphere. Politics became more and more confused because it splintered into countless selfish interests. There was no longer any global or cosmopolitan thinking; the Nazis instead found the ground fertile for the traditional resentments they voiced. So it was easy to return to primordial instincts, to the ancestors, to the race, to the lowest values that spoke directly to the blood.

They remained fixed ideals which people could work for even during times when they seemed very distant from reality. They were a means of looking far ahead, a long-term aim, like a wish that was to be realized independently of the current situation. This type of politics corresponded fully to the axiom according to which the more radical the proposals the greater the consensus, and still nowadays it is so. According to Ian Kershaw the radicalism, indispensable element of the NSDAP, created and fueled the consensus[37]. In other words, the German people needed someone who would make them feel strong again.

I think that this description could fit the current situation of our Europe for what concerns the right and extremist parties creating more and more consensus in different European countries (Hungary, Poland, Italy, Austria and many others). Yet it is quite sure (or not?) that no new national socialist movement is at our horizons, but how can we consider all those mass movements evoking the closure of the borders, racial affirmation, social diversity and immigrants' repression? Are they only a parenthesis or have the chance to gain votes and attention in our political panorama? Saul Friedländer observes with troubles that in Germany and in the world there is a comeback of national extremist movements[38].

Over time many people have variously interpreted the success of the NSDAP, identifying similar reasons to those mentioned above and also contrasting reasons. Are those factors not active in our societies today? How can the "traditional" political system face the advancement of new political parties and grassroots movement refusing the EU and affirming the necessity to close the borders, even with walls? By reflecting of what has happened in the past, man can always find the right solution in order to prevent any political deviation with no return.

\section{REFERENCES}

[1] Source: David C. Large, Hitlers München (München, 1998), p. 20.

[2] Literally: 'education and wealth'; the combination of a good education and the possession of wealth.

[3] Large, p. 26.

[4] Max Weber (1864-1920), sociologist, philosopher, economist, historian. His thesis about the power and the power legitimation were and are very famous in Europe and are still studied in the political science domain. He is one of the co-founder of the sociology (together with Karl Marx and Emile Durkheim.

[5] Carl Schmitt, Teologia politica, p. 39, cited in Zygmunt Bauman, Vite che non possiamo permetterci (Bari, 2010), p. 77. Carl Schmitt (1888-1985) was a jurist and a political theorist. His theories about the nature of the policy were very well known in the period and the same are nowadays.

[6] Even Hitler's most conservative allies thought he would abandon his most radical plans after having achieved power. Others, such as Von Papen, were convinced Hitler would only last a few months. But from the very beginning of his government the demagogic Hitler showed himself to be a very adept politician. The comment on the rise to power of Hitler was made years after the event by a politician from Munich. Cited in Joachim Fest, Hitler - Eine Biographie (Berlin, 2008), p. 169.

[7] The Republic of Weimar was founded on the 9 November 1918. The beginning of the new year was greeted as the beginning of the resurrection of a new country after the defeat of the war.

[8] The Treaty of Versailles is the agreement, which put an end to the WWI. Germany was forced to sign it, due to the fact that it lost the war. This treaty has been seen in Germany as a shame and therefore the most part of the population kept on considering it as a clamorous defeat for long years.

[9] Ibidem, pp. 218-219. The following citation and the text in inverted commas further down are taken from the same pages of the same text.

[10] Kurt Sontheimer, Antidemokratische Denken in der Weimarer Republik - Die politischen Ideen des deutschen Nationalismus zwischen 1919 und 1933 (München, 1978), p. 219.

[11] Hans Kelsen was an Austrian jurist and philosopher, born in Prague in 1881 and died in the USA in 1973. Colleague of Sigmund Freud, he wrote also in the field of sociology and social psychology. He was remembered for his strong defense of the democracy and of the concept of democracy before the NS success. 
[12] Cit. in Helmut F. Pfanner, Hanns Johst (The Hague, 1970), p. 151, cited in George L. Mosse, La nazionalizzazione delle masse (Bologna, 1975), p. 242.

[13] Fest, p. 235.

[14] Thus speaks Miklas, one of Klaus Mann's characters, a nationalist fanatic who will later be disappointed with the corruption of the National Socialist regime in which he had, like so many others, placed all his hope. Klaus Mann, Mephisto (Hamburg, 1981), p. 169.

[15] M. Loecke, Die blockierte Republik - Deutschland zwischen Wahn und Wirklichkeit, (Baden Baden, 2004), p. 31.

[16] K. Sontheimer, cited, p. 242.

[17] Thus Hitler in his Mein Kampf. Cited by G.L.Mosse, cited, p. 2.

[18] Fest, p. 71.

[19] This and the quotation above are from: Loecke, p. 13, 14 respectively.

[20] See http://it.wikipedia.org/wiki/Alfred_Rosenberg.

[21] Hermann Wilhelm, Dichter, Denker, Fememörder Rechtradikalismus und Antisemitismus in München von der Jahrhundertwende bis 1921 (Berlin, 1989), p. 167.

[22] Actually his membership number was 55, because it was the official policy of the NSDAP to put the number 5 in front of all membership numbers in order to artificially inflate the party's membership.

[23] Falk Wiesemann, Die Vorgeschichte der nationalsozialistischen Machtübernahme in Bayern 1932/33, (Berlin, 1975), p. 80.

[24] In his essays, the American political sociologist Seymour Martin Lypset (1991-2006) tried to do a portrait of the social groups dominating the NSDAP, but, as a matter of fact, the hypothesis made were not always supported by documents of the period stating the social level of the adherents to the Hitler's party. Cfr: Peter H. Merkl, Frustrated Upward Mobility - Political Violence Under the Swastika: 581 Early Nazis (Princeton, 1975) pp. 62-76.

[25] Source: Michael H. Kater, The Nazi Party - A social profile of members and leaders - 1915-1945 (Oxford, 1983), p. 242.

[26] The Nobel laureate was closely involved with the Deutsche Physik movement within the Nazi regime. He received his education at the University of Munich and developed his career in Germany, paid with the highest prize in 1919. He joined the Nazi party and was working against the "Jewish physics" and Albert Einstein theories in particular. With him another Nobel laureate, Philipp Leonard, was active.

[27] Fest, p. 228.

[28] Between the end of the nineteenth century and the start of twentieth Karl Lueger was mayor of Vienna for a period unrivaled in the history of Austrian towns. He founded the Christian-Socialist party, from which Hitler took many ideas and strategies, such as antisemitism, rallies, and the emphasis on direct contact with the masses and on rhetorical skills. Hitler was in fact in Vienna during the period in which Karl Lueger rose to power, and he was impressed by Lueger. His appreciation of him, which was in many respects revolutionary, is evidenced by Mein Kampf.

[29] The Bavarian Council Republic (or Bavarian Soviet Republic) was established in early November 1918, after the communists suddenly gained power following a coup in Munich. Only some months after, in May the following year a bloody and terrible repression was carried out. There were many deaths, especially among the right wingers who rebelled against the communist republic. And along with Wiesemann, «Their deaths gave a new impulse and a wide diffusion to right-wing ideas. The traumatic historical event of the Bavarian Council Republic resulted once again in a shift to the right, even in liberal, middle-class and traditionally left-wing circles where people now regarded democratic reform as an impossibility» (F. Wiesemann, cited, p. 69).

[30] The program was written by Hitler, Drexler and Feder and was addressed to the workers in particular. Cfr. Kater, p. 20.

[31] Ibidem, p. 49.

[32] Thus remarked Milton Mayer in 1955. Kater, p. 73.

[33] On this topic see also: Hans Mommsen, Der Nationalsozialismus und die deutsche Gesellschaft Ausgewählte Aufsätze (Hamburg, 1991), p. 47.

[34] Ibidem, p. 68.

[35] Mosse, p. 25.

[36] Ian Kershaw, Der NS State, Hamburg, 2009.

[37] Mosse, p. 8.

[38] Cfr. Süddeutsche Zeitung, 30 Sep. 2016, p. 6. 